\title{
Research on the Minority Preparatory College Chinese Teaching Design based on Task Driven Teaching Method
}

\author{
YuMin \\ Nanchang Institute of Science \& Technology, Nanchang 330108, China
}

Keywords: Task driven, Language learning, Learning interest, Chinese teaching, Preparatory course.

\begin{abstract}
College Chinese is a compulsory public class in preparatory college, but in recent years, a number of ethnic minority college faced with the different degree of teaching difficulties, which mainly reflected in the teachers teach and students difficult to learn. From present situation of the minority preparatory Chinese learning, this paper carries out inquiry analysis of the problems and its formation in the teaching process, and proposes the corresponding reform strategy. In order to change the present teaching situation of the minority preparatory college, the task driven teaching method introduces into Chinese teaching process to improve the teaching effect. Through the task driven and group collaboration teaching methods, students can get a strong interest in learning and driving force, which can make a common progress between preparatory class and Chinese teaching class students, to improve the teaching effect of Chinese language.
\end{abstract}

\section{Introduction}

In recent years, there are some Chinese languages teaching problems in Colleges, in which teaching and learning are the most prominent problem, and these problems are more serious for the minority students [1-3]. In addition to the accumulation of daily knowledge, college Chinese learning also need the guidance of teachers, teachers are particularly important for the minority students [4]. The basis of minority students is poor, how to master the knowledge of modern Chinese language is the difficulty of teaching, teachers should be combined with the actual learning conditions of minority students, innovative teaching methods can help students overcome this dilemma and improve the performance of Chinese learning.

\section{Minority Preparatory College Teaching and Students Learning Situation}

For different teaching object, College Chinese's teaching objective, plan and content are different; for Chinese teaching students, we take Chinese classical literary works as the content, while the minority students mainly take the modern text as the teaching content $[5,6]$. However, the division of the teaching content will have a negative impact on the ethnic minorities. The minority preparatory course is a year in general, entering the four year Chinese teaching system after a year, which means that the use of a year's time will be incorporated into the Chinese teaching class [7-9]. These students and Chinese students also have a big gap, the Chinese is equivalent to a foreign language for a minority of students, there is a big difference with its mother tongue, which makes the students show a lot of difficulties, so as to affect the students' learning interest. We investigated the teaching and learning situation of the students in the minority preparatory college, research content is the teaching effect of Chinese class, the results are as shown in Table 1.

Based on the survey data of Chinese teaching effect in the minority preparatory college, we can find that minority preparatory course students and Chinese teaching students are arranged in a class, there are some difficulties in teaching. According to the current teaching mode and method, the minority preparatory students cannot understand the real Chinese knowledge in the classroom, therefore according to the level of Chinese language teaching, the students can not apply to the minority students, but Chinese teaching students are according to minority preparatory course teaching, the contents will be too simple, it is not conducive to the further study and understanding of 
College Chinese knowledge, so we need to change the teaching mode and methods, to further improve the teaching effect.

Table 1. Teaching effect questionnaire

\begin{tabular}{|l|c|c|c|}
\hline Student community & Fully understand & Basic understand & Most incomprehensible \\
\hline Correspondence class & $86 \%$ & $11 \%$ & $3 \%$ \\
\hline Preparatory class & $52 \%$ & $26 \%$ & $22 \%$ \\
\hline Minority Chinese textbook & $32 \%$ & $26 \%$ & $42 \%$ \\
\hline
\end{tabular}

\section{The Characteristics and Implementation of Minority Preparatory College Teaching Task Driving Method}

In order to change the present teaching situation of the minority preparatory college, and improve the teaching effect, task driven teaching method is introduced into the teaching class, the use of the cooperative teaching method makes the Chinese teaching students and preparatory class students to carry on cooperate, strengthening the communication between teachers and students, and the teaching can make the teaching adjustment program to meet the needs of the Chinese language teaching and preparatory class students [10-12]. In order to achieve this goal, the teaching process needs to have a certain characteristic, its concrete implementation is:

The establishment of learning group. The university study is different from the middle school stage, there is more business time and less academic tasks, teachers are less understood students and very difficult to grasp the basic knowledge of the students. In the course of Chinese teaching, teachers can divide the students into several groups, each group determines a group leader, and the team leader will gather the basic knowledge of the team members, so that teachers can grasp the knowledge of the students in a timely manner, strengthening the communication between teachers and students. Chinese language teaching and preparatory courses direct distribution in each group, the group can strengthen cooperation between the team members, so that the Chinese class students promote the preparatory class, which improve the overall learning effect. The teacher can guide the Chinese learning of the group and assign each group Chinese learning tasks, so as to improve the learning effect of the language through the students' cooperation to complete.

Task driven. Task teaching method is that teachers are assigned to the learning task according to the group, in order to improve the students' interest in learning rather than blindly the imparting knowledge and cramming teaching. The role of the teacher has changed in task driven teaching method, the teacher becomes a student's guide, which specify the direction for finding learning materials and collecting information. The task driven method can be placed outside the classroom, so that students can enrich their leisure life, to improve the teaching efficiency of the classroom by not using the way of classroom learning time. The difficulty of the extracurricular tasks needs to be appropriate, otherwise the students can not complete the task, which will reduce the learning effect, so that students have little success.

Classroom interaction. In the classroom, the teachers need give students a lot of time in addition to the completion of the basic teaching tasks, on the one hand, the completion of the task can be reported and communication to improve students' interest in the task; on the other hand, the teachers for the classroom knowledge can communicate with students, to exercise students' courage and improve the spoken language ability. In the course of real time teaching, we can let each group of students speak, to meet each student's desire to express, and to provide greater power for the completion of the next task,.

\section{Design of Minority Preparatory College Teaching Form}

Task teaching method must take the task as the center, the teacher will be the language knowledge implicit in a typical task, and these tasks cannot be fabricated, but need to the actual match, which requires teachers to grasp the teaching content, collecting various learning information channels, expanding and improving their knowledge [13]. In the task driven teaching, the design of the task is 
very important, we should pay attention to the design of the basic tasks, but also make the task with novel.

Organizing story and debate. For some writing teaching, teachers can give students the task and collect the story associated with text. At the beginning of the classroom, each student speaks a story related to the text, they can also debate the relevant point on the text, to bring the debate results introduced by teaching work, which can stimulate the students' learning interest, but also improve the teaching effect of the classroom.

Making presentation. With the modern education technology, teachers can set up the presentation task, guiding students to read the text carefully and giving full play to imagination and association, then teachers display in the form of slides to active classroom learning atmosphere.

Writing character evaluation. In college Chinese task driving teaching method, teachers can decorate some biographical evaluation task. For the some writing real figures and historical figures, teachers can arrange students to search the relevant information and write the task, and then through the matter, portraying characters and character and shaping Chinese reference value in the real life.

Writing guide words, articles, etc.. For the writing scenery, teachers can guide the students to read the text carefully, collecting the network information, writing a guide words on the spot, and then the use of network multimedia information does a live speech PPT to explain the visit, which can improve students' learning interest and learning effect.

Guiding the students to perform the text role. Teachers can be a group for the unit to carry out the role of the text, through the adaptation story and drama form, teachers guide students to imitate the characters in the text, and teachers require students group performances with the form of perform, the use of form drives teaching.

Changing the ancient poetry, poetry, etc.. Teachers can give students a set of poems and poems to rewrite the characters, the ancient poetry or poetry change to vernacular Chinese. For students, teachers can inspire their thinking and imagination and stimulate students' interest, which become the driving force for their learning.

\section{Summary}

The purpose of Chinese teaching reform in preparatory course is to make a number of students at different levels to obtain the development, on the basis of cooperation, students and Chinese language teaching students can progress together, enjoying the learning fun, acquiring knowledge and improving human qualities. For the ethnic preparatory college, it is imperative to reform the teaching, teachers should reasonable determine teaching goal, teaching task and innovative teaching methods according to the actual situation of the students, in order to teach students in accordance with their aptitude, close to the needs of students and really improve students to acquire knowledge and skills.

\section{References}

[1] J.F. Wang. Application of hierarchical teaching strategies in University Chinese teaching. Chinese Education Innovation Herald, 2013, 47 (1): 66-67.

[2] Y. Yang. The advantages and disadvantages of multimedia teaching in English teaching. Journal of Jilin radio and Television University, 2014(6): 146-147.

[3] Y.H. Zhang. Study on the dynamic evaluation model of College English web writing teaching. Foreign language circles, 2014(4): 73-81.

[4] X.Q. Wang. Theory and practice of higher mathematics stratified teaching mode. Jilin education, 2013(11): 20- 21.

[5] D.H. Mao. Research on the implementation of the teaching of higher vocational mathematics. Journal of Chongqing Vocational and Technical College, 2014, 16(4): 43- 44.

[6] S.M. Su. The study on the job burnout of American teachers. Education, 2013(3): 209-217. 
[7] L.J. Ceng, X.C. Wu. Research on teacher burnout. Education research, 2014(11): 79-81.

[8] L. Jiang, F.G. Tang, Z.C. Xiao. Review of foreign teachers' job burnout research. Education and occupation, 2014(5): 65-67.

[9] B.P. Chen, A.L. Hu. Analysis of the stratified teaching mode of higher education popularization stage. Journal of Liaoning radio and TV University, 2014(2): 51- 52.

[10] X.Y. Liu. Research and practice on "higher mathematics" level teaching assessment method in higher vocational. China school education, 2014(3): 101 - 111.

[11] X.F. Han. The thinking of higher mathematics teaching current situation and its stratification teaching. Journal of Lvliang College, 2013, 23(1): 40- 41.

[12] L. Fu. The use of hierarchical teaching in English Teaching. Hope monthly, 2013(8):100-101.

[13] X.Q. Yu. The formation and breakthrough of "Matthew effect" in basic education. Teaching and management, 2013(9): 60-61. 